\title{
EMPIRE AS MATERIAl SETTING AND HEURISTIC GRID FOR NEW TESTAMENT INTERPRETATION: COMMENTS ON THE VALUE OF POSTCOLONIAL CRITICISM
}

Author:

Jeremy Punt ${ }^{1}$

\section{Affiliation:}

${ }^{1}$ Department of Old

and New Testament,

University of Stellenbosch,

South Africa

\section{Correspondence to: \\ Jeremy Punt}

email:

jpunt@sun.ac.za

Postal address:

Department of Old and New Testament, Faculty of Theology, Stellenbosch University, Private Bag

X1314, Matieland 7602, South Africa

\section{Keywords:}

postcolonial; empire; Paul; biblical hermeneutics; Roman

\section{Dates:}

Received: 11 Aug. 2009 Accepted: 24 Dec. 2009 Published: 17 June 2010

How to cite this article: Punt, J., 2010, 'Empire as material setting and heuristic grid for New Testament interpretation: Comments on the value of postcolonial criticism', HTS Teologiese Studies/ Theological Studies 66(1), Art. \#330, 7 pages. DOI: 10.4102/hts.v66i1.330

This article is available at:

http:/ / www.hts.org.za

Note:

Edited version of a paper read at the International SBL Meeting, Pontifical Biblical Institute, Rome, 30 June-04 July 2009.

(C) 2010. The Authors. Licensee: OpenJournals Publishing. This work is licensed under the Creative Commons Attribution License.

\section{ABSTRACT}

Using postcolonial analysis to account for the Roman Empire's pervasive presence in and influence on early Jesus-follower communities (early Christians), as depicted in New Testament texts, is both evident (given its usefulness for analysing situations of unequal power relationships) and complicated. The complications are due partly to the material and conceptual potential and constraints inherent in postcolonial biblical studies, as well as to the complexities involved in dealing with empire and imperialism. The study of the Roman Empire, as far as its impact on early Christianity and (in this article) on the letters of Paul is concerned, requires attention to Empire's material manifestation, ideological support for Empire, and religious aspects - issues that are identified and briefly discussed. Empire can be understood in many different ways, but it was also constantly constructed and negotiated by both the powerful and the subjugated and therefore attention is required for its possible reach, uses and the purposeful application of discursive power in New Testament texts that were contemporary with Empire.

\section{INTRODUCTION}

The materiality of life in the first-century CE Mediterranean context was determined largely by the omnipresent and omnipotent Roman Empire in its various forms and guises. True to imperial ideology, the Empire made its presence felt in tangible and visible ways. ${ }^{1}$ Regular contact with the material reality of imperial imposition was par for the course for first-century people, constantly reinforced by visual images and verbal and written decrees, through military presence and social systems such as patronage, held in place in ways that reinforced both the Roman imperial presence and the people's sense of submissiveness to Empire. At the same time, but more difficult to account for with immediate references, since it goes beyond citing New Testament texts, requiring attention for the use of discursive power, the context of an all-pervasive Roman imperial presence and practice informed the consciousness and worldview of people around the Mediterranean in the first century CE. In short, material and historical imperialism, as well as discursive imperialism, informed, sculpted and determined the daily lives of people in a myriad of ways, also at the level of consciousness, through ideology. ${ }^{2}$

During the last decade or two it has become clear that a new grammar and vocabulary are needed to understand first-century power relations and their structural organisations, especially in the light of the strong apocalyptic framework of many New Testament texts, with their bold challenge to the Roman Empire through privileging God's imperial designs. In short, it has become increasingly important to account for the empire as both material setting and as heuristic grid. ${ }^{3}$ Historical studies have been, and remain, valuable for investigating the nature, reach and impact of the first-century Roman Empire. However, accounting for Empire as a horizon of understanding in New Testament studies has invoked the use of postcolonial criticism and related categories to account for the impact of the Roman Empire on early Christianity, ${ }^{4}$ given the problematic relationship between texts and socio-historical context (see Whitelam 1998:35-49, for example). The purpose of this short article is to acknowledge the role of Empire as material setting and heuristic grid in the interpretation of New Testament texts in general and Pauline texts in particular, briefly considering the usefulness of a postcolonial approach when using Empire as heuristic grid.

\section{EMPIRE IN THE FIRST-CENTURY CE}

\section{Paul's material setting}

Accounting for the Roman Empire ${ }^{5}$ as material setting during New Testament times is of course more

1.'The royal family, both the emperor himself and his predecessors, and his wife and children, were well known through statues and coins. From Spain to Syria, everybody knew about Rome, what it stood for, what it did, and who was in charge of it' (Wright 2005:64)

2.In accounting for Empire as a presence behind, and influence on, New Testament texts, anachronistic scenarios should be avoided, here as much as elsewhere. Jesus and his followers were not the archetypical freedom fighters who, along modern lines of thinking, had their eyes set on reshaping social reality by removing an oppressive regime. However, claims such as 'Jesus and the prophetic tradition, however, show no interest in structures, democratic or any other. They are only interested in how power is exercised, and to what end' (Bryan 2005:127) are probably also and equally blunt. Moreover, claims such as the latter tend to divorce agency and purpose from institution, both illegitimately and in a way foreign to the ancient time, and seem to presuppose contemporary structural change as a possibility, notwithstanding the autocratic, at best oligarchic, rule of Empire, whether directly through its administrative and military apparatus or through its local representatives, in a hierarchically ordered world; not to mention the apocalyptic scenario that presupposed the replacement of existing human structures with a divine dispensation.

3.Important work on the materiality of Empire and its heuristic value has been done, in particular, by Carter (2006), Elliott (1994), Horsley (1997; 2000), Lopez (2008) and others, while a postcolonial optic is presented by, among others, Moore (2006a), and Segovia and
Sugirtharajah (2007).

4.With the rise of postcolonial studies and approaches in biblical, theological and religious studies, warnings have been sounded to avoid the pitfall of recent empire studies, which tend to lean toward the rehabilitation of certain texts rather than a critical engagement with them. Furthermore, a more nuanced approach is required when discussing postcolonial and various types of resistance literature, given the it draws upon have to privege and power- power and language (the p). it draws upon have to be accounted for (Schüssler Fiorenza 2007:4-5).

5.Some scholars rightly warn against a too simplistic equation of all forms of Roman internal rule as empire: 'It is probably more appropriate ' 'republic' and 'principate' since even before the emergence of the 'emperors' of Rome, the Romans controlled foreign territories and this could be called 'empire' (Hollingshead 1998:26 n14). 
complicated ${ }^{6}$ than listing some categories of overt manifestation in imperial structures, systems and mechanisms. Such material aspects of Empire are important, but the complex nature of each of these entities, as well as their entanglement with a range of other (related and, for our context, unrelated) items, often make their description difficult. A particular challenge in adequately acknowledging the reach and impact of the Roman Empire is related to the imperial presence and power already involved in or at least intimately related to various other social and economic structures and systems on different levels in first-century society. The wealth and diversity of various studies on Empire ancient and modern has made an important contribution to a better understanding of the materiality of the Roman Empire in New Testament times.

The Roman Empire was propped up by a number of important supports, including military conquest, the system of patronage, the rhetoric of peace, ${ }^{8}$ prosperity and concord and the imperial cult (see Horsley 1997:87-90, 2000:74-82 in this regard). However Empire's pervasive influence was probably at its strongest on an ideological level ${ }^{9}$ and interconnected with various dimensions of first-century life across the spectrum of communities spread out geographically, thus requiring a broad-spectrum approach when discussing Empire during the time of the New Testament. ${ }^{10}$ In fact, subsequent to the success of military conquest, it would be the rhetoric of Empire that continuously inscribed and replicated the language of power and domination required for its continuance. Discussing these and other elements separately is not intended to deny that materiality and ideology feed off one another.

The overt manifestation of the Roman Empire is a good place to begin an investigation of its nature and the impact it had on New Testament texts. The basis of Roman power was most evidently and forcefully situated in its vast military might, a force of generally well-trained and well-resourced legions, which generally operated efficiently and ruthlessly. Punishment for dissention and sedition was harsh and the cross ${ }^{11}$ was the ultimate symbol of Roman power and cruel brutality. Roman justice was not limited to foreigners and the lower classes; at times even those Roman provincial governors accused of wrongdoing were held accountable before the courts. ${ }^{12}$ Roman taxes cut a broad swathe

6.Cf. the two typically modern dangers to avoid when thinking about first-century politics, as suggested by Wright (2005:59-60): a fixed map of post-Enlightenment political option on a left-to-right sliding scale and the separation of domains of life, such as theology and society, or religion and politics. Regarding the study of empire, three important dimensions are: firstly, empire as 'structural reality', comprised of and

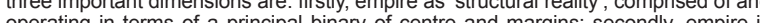
opera un ifor not a unifom phenomenon in a temporal or spatial sense, but in fact 'differentiated in extent that it influences and impacts in direct and indirect ways (Segovia 1998:56-57).

7.For studies on the Roman Empire see Garnsey and Saller (1987): Garnsey and Whittaker (1978): Millar (1977); and Scarre (1995); for modern empire studies, see Boron (2004); and Hardt and Negri (2000; 2004). The studies on the interface of the New Testament and Roman Empire in the bibliography are the tip of the proverbial New Tes

8.Concepts such as peace were, of course, filled out differently by those inside and outside the Empire; Tacitus puts the following words about the Romans in the mouth of the British rebel commander Calgucus: 'To robbery, butchery and rapine, they give the name of "government"; they create a desolation and call it "peace"' (in Hollingshead 1998:26 n16).

9.An empire is generally driven by a sense of moral virtue and operates with a vision of re-ordering the world's power relations for the sake and betterment of all.

10. The widespread, insidious presence of Empire in NT texts gives rise to questions about culture, ideology and power, as suggested by Segovia (1998:57-58): 'How about culture, ideology and power, as suggested by Segovia (1998:57-58): 'How
do the margins look at the 'world' - a world dominated by the reality of empire do the margins look at the 'world' - a world dominated by the reality of empire -
and fashion life in such a world? How does the center regard and treat the margins and fashion life in such a world? How does the center regard and treat the margins
in light of its own view of the 'world' and life in that world? What images and
representations of the other-world arise from either side? How is history conceived representations of the other-world arise from either side? How is history conceived
and constructed by both sides? How is the 'other' regarded and represented? What conceptions of oppression and justice are to be found?

11.Unlike the Persians and Carthaginians, who used crucifixion against high officials and commanders, the Romans used it primarily against the low classes (slaves, violent criminals and unruly elements) and political threats, which would have included those considered traitors and deserters; cf. Hengel (1977:87).

12.'Rome's system of justice - which, to be fair, was often a considerable improvement on the local systems over which it superimposed itself - supplied tribunals and courts of law answerable, ultimately, to the emperor himself' (Wright 2005:64). and while legitimised as recompense for the privileges provided by Empire, such as peace and security, or freedom and justice, they mostly served to increase the magnificence and opulence of the elite, who ultimately benefitted from imperial machinations.

For the majority of people in New Testament times, the local elites were predominantly the cutting edge of Empire, its public face and an important aspect of the imperial machinery. ${ }^{13}$ Through their 'government without bureaucracy' (Garnsey \& Saller 1987:20-40) the Roman Empire yielded administrative authority to indigenous elites. ${ }^{14}$ This had a twofold purpose. On the one hand, the local elites kept the imperial wheels turning in many ways, for instance ensuring the collection of tribute, organising business and politics and generally garnering support for Empire through bestowing benevolence and undertaking public-works programmes. On the other hand, the elites were an important aspect of the imperial divide-and-rule politics (Moore 2006b:199), since popular resentment and even uprisings could be blamed on them while the imperial powers retained ultimate authority by remaining remote and unavailable. ${ }^{15}$

A vital component of the first-century imperial footprint was, secondly, its ideological framework. ${ }^{16}$ By the beginning of the first century, the Roman Empire had established itself as the supreme political power, after it had some decades before conclusively dealt with its main rival, Carthage, and largely stabilised internal divisions, consolidating its power, influence and wealth. Imperial ideology was intimately and reciprocally connected to symbols of its power, with the symbols informing ideology and the latter sustaining and providing purpose and justification for the former. ${ }^{17}$ The Roman imperial ideology was built on revisiting the ideals of the old republic and presenting itself as a democratic institution -this pretence being underwritten by notions of liberty and justice. ${ }^{18}$ Moreover, following the civil war, Augustus was often deemed the one who brought peace to the Roman Empire and therefore to the world at large. ${ }^{19}$ In the end, '[f]reedom, justice, peace and salvation were the imperial themes that you could expect to meet in the mass media of the ancient world, that is, on statues, on coins, in poetry and song and speeches' (Wrigh 2005:63). The claims to such values and achievements were ultimately ascribed to the benevolence of the emperor and were individually and collectively presented as euangelion or 'good news', the same word used, of course, by the early followers of Jesus in describing his life, work and message. Poets and historians like Virgil, Horace, Livy and others created, in their different ways, a grand narrative of Empire - a long eschatology that had reached its climax. ${ }^{20}$ In the court of Augustus, the story

13. Here the importance of the patronage system should be considered within the context of the emperor as ultimate patron, who devolved his power down to other patrons, each with a circle of influence as well as a group of underling patrons, continuing in a never-ending extension of the patronage system. 'Far from trying to eradicate traditional patronage relationships, emperors encouraged their continuation, in part because they were the main mechanism for recruitment of new members of the imperial elite' (Garnsey \& Saller 1987:201); (cf. Chow [1997]).

14.Cassidy (2001:5-18) is of the opinion that beyond the basic characteristics of Empire (as consisting of military power, political structures and taxation), it attracted local populations in four ways (all providing tangible benefits for the populations of subjugated territories): public works; peace and order; effective administration (incl. subjugated territories): public works; peace and order; effective administral
Roman citizenship benefits as a major prize); and imperial propaganda.

15.In exceptional circumstances, such as the Jewish war in $66 \mathrm{CE}$, 'the ultimate authority finds it necessary temporarily to relinquish its godlike remoteness and relative invisibility in order to intervene decisively and irresistibly in the corrupt affairs of its creatures in an attempt to contain the chaos that its own administrative policies has created' (Moore 2006b:199).

16.Dealing with the ideological aspect of Empire is important because, "[i]n practical terms, the Roman way was dominant because the Romans exercised political control of the region, but the Romans never set out to eliminate the cultures they absorbed' of the region, but the Romans never set out to eliminate the cultures they
(Hollingshead 1998:14). See Richey (2007:27-65) on Augustan ideology.

17.'In a situation of conflict, those who exercise power will seek to do so not only in terms of control of wealth creation but also in terms of the ideas which can justify and terms of control of wealth creation but also in terms of the ideas
support the way in which the world is run' (Rowland 2006:659).

18.'The republic has long prided itself on its justice, and in the middle years of Augustus' reign "lustitia", too, became an official goddess: Rome possessed Justice, and had the obligation to share it with the rest of the world' (Wright 2005:63).

19. Amidst the ideological onslaught of the Empire with its propaganda, pockets of dissent were still found of Wright (2005:63); Hollingshead (1998.26 n16). 
of Rome was told as a narrative of culmination - a long process of training and preparation that would see the Empire assume its destiny as ruler of the world. ${ }^{21}$

At times, the emperors themselves engaged in ideology mongering, as in the case of Augustus, who had his achievements (on behalf of the Roman people and the world) inscribed in various texts and on various memorials. ${ }^{22}$ Rather than the domination and subjection of other peoples, the actions of the emperors are described as acts bestowing the friendship and fidelity of the Roman people on the peoples of the world. The defeat of other peoples through conquest and warfare is described as the miraculous achievement of the Pax Romana, as worldwide peace. 'The ideology of Roman supremacy involved the inferiority of other peoples who were destined to be subservient to the Romans; within this ideology, the Jews were on occasion singled out as a people "born to servitude"' (Elliott 2007:187). The breadth and depth of the imperial ideology and propaganda meant that the Roman world was saturated 'with a carefully managed repertoire of images depicting the piety and benevolent potency of the emperor, and of the routinised representations and celebrations of those virtues through a ubiquitous imperial cult (Elliott 2007:183).

And this introduces a third, religious, dimension of Empire, one which featured most prominently in the past, when biblical scholars considered imperial influence in their studies on the New Testament. Generally, such studies focussed strongly on the emperor cult $^{23}$ with some scholars today arguing that, by the middle of the first-century $\mathrm{CE}$, the emperor cult was the fastest growing religion of that time (Wright 2005:64). In addition to encouraging the worship of the gods of Empire, the emperors were often included among those worshipped. While few emperors attempted to claim divine honours for themselves, ${ }^{24}$ their insistence on the divinity of their predecessors often served to reinforce their own positions of power. This practice ensured that the claim by any given, serving emperor to be a 'son of god' was not uncommon at the time, even if the relationship between the emperor and his predecessor was at most one of adoptive kinship, as in the case of Octavian/Augustus.

The emperor cult was one, albeit an important, element of a much more pervasive religion-saturated imperial system. ${ }^{25}$ Augustus,

20.In Aeneid 1:255-296, Virgil portrays how, in the aftermath of the Trojan War, Jove promised the goddess Venus that her beloved hero Aeneid would both find a great city and subdue the proud nations. His descendants would prosper but also control all sea and land: Romulus, one of his descendants and the legendary founder of Rome, was destined to rule forever as master of the world (cf. Elliott 2007:183).

21.'This ideology, like most imperial rhetoric, got rewritten as the empire wore on, but This ideology, like most imperial rhetoric, got rewritten as the empire wore on, but managed to survive the ridiculous chaos of CE 69 and carry on well into subsequent centuries' (Wright 2005.64). After the murder of Jullus Caesar and the civil war which also saw the collapse of the Roman Republic, Octavian, as Caesar's adopted heir, was eventually victorious over Anthony (who, of course, toward the end, joined forces with Cleopatra) at Actium in $31 \mathrm{BCE}$, and took the title Augustus. After ruling for more than four decades around the turn of the era (27 BCE to $14 \mathrm{CE})$, his son Tiberius took over and consolidated his work. After him, in 37-41 CE, Gaius Caligula made a disaster of his rule, and was followed by the feeble but cunning Claudius, after whose death in 54 CE Nero come to power as the new hope for the Empire. Upon Nero's death in 68 CE (accompanied by contrasting assessments of his rule), the year of four emperors followed. After Galba, Otho, and Vitellius almost ran the Empire into the ground, it was Vespasian who established a new dynasty that saw the Empire encapsulating most of the Mediterranean and new dynasty the hinterland as well (White 1999:110-135; Wright 2005:62-63).

22.In various self-serving, propagandist texts, the emperors are lauded for their contribution to securing peace on earth: Augustus declared his own agency as one of peace and security (Res Gestae Divi Augusti 13); supported by Virgil (Aeneid 1:291-296), who acted as revisionist-apologist for Roman glory from the early days; cf. also Calpernius Siculus (Eclogue 1:45-54) on Nero's cosmic victory over the bound enemy in the 'impious war"; (cf. Elliott 1994:185).

23.The emperor cult 'served three main functions: the diffusion of imperial ideology; the focusing of the loyalty of subjects on the emperor; and the social and political advancement of these provincials who presided over its operation' (Garnsey \& Saller 1987:202); cf. also Friesen (2001) and Price (1984).

24. Initially, Roman emperors were declared divine by the Senate only posthumously. Outside of Rome and already during the time of the New Testament, however, the Outside of Rom with the emperor frequently being portrayed as the divine 'saviour' of the empire (Ehrman 2008:28) for example, was hailed by contemporary poets for what was described as his remarkable piety. This piety was often given as the reason for his successful establishment of the Empire. ${ }^{26}$ On the Ara Pacis, the Augustan Peace altar in Rome, ${ }^{27}$ the image of the pious Trojan hero, Aeneas, making sacrifices on the shore of Latium was paired with a similarly pious Augustus offering sacrifices on behalf of the Roman people (Elliott 2007:183).

In the eastern part of the Empire, where rulers were traditionally regarded as divine, the emperor cult grew particularly strong and as a result saw cities benefit enormously by receiving rewards of various kinds. Building programmes generally led to the erection of temples in honour of the emperor, often accompanied by a restructuring of the city, as in the case of Ephesus and was accompanied by various other activities such as games, festivals and other celebrations in honour of the emperor. Given the imperial military might through which the emperor laid claim to all territory and people '[a]s far as most of the Roman world was concerned, the "divinity" of the emperor was obvious and uncontroversial' (Wright 2005:65; cf. Richey 2007:34-40).

Everything considered, the Roman Empire did not have to forcefeed its imperial subjects its ideology and propaganda, or impose accompanying socio-cultural, political and religious rituals, since the provincial elites were eager to develop their own versions of imperial splendour in imagery and ritual to demonstrate the new configuration of power in their cities. Competition with their counterparts elsewhere for the best reproduction of Caesar's example of ritualised piety and benevolence soon led to the blurring of boundaries between the emperor and the elites - to such an extent that such values were identified with each other (Elliott 2007:183). Imposing the emperor-cult through the threat of force would prove unnecessary, in any case, as long as the threat of violent action was considered real enough and that the perceived benefits of imperial rule, such as safety and stability, seemed to overwhelm its distractions. ${ }^{28}$

\section{PAUL, EMPIRE AND POSTCOLONIAL STUDIES}

\section{Empire as heuristic grid $^{29}$}

It is on this imperial canvas, then, that a portrayal of the earliest communities of Jesus-followers can be painted by means of broad strokes (as far as Empire was concerned), but also with the purposefully directed strokes (as far as each Letter's own distinct purpose was concerned) of the various, contingent Pauline Letters in the New Testament. Empire was a material reality for the New Testament authors and certainly also for Paul, with his metropolitan make-up and extensive travel experience. Paul's urban-focussed mission would have brought him in close

25.This cult should be understood in conjunction with Empire's other aspects. '[G] overnment and religion both functioned, theoretically, to secure the same ends of making life prosperous, meaningful, and happy. The gods brought peace and prosperity and made the state great. In turn, the state sponsored and encouraged the worship of gods' (Ehrman 2008:27)

26. See White (1999:110-135) for a discussion on piety in Augustus' political agenda amid public grandeur and civic works programmes.

27. The Ara Pacis Augustae was erected on the field of Mars in Rome and the building of Vespasian's Templum Pacis (Peace Temple) in 75 CE emphasised the Pax Romana as the domination of other nations (cf. Crossan \& Reed 2004; Swartley 2006:37).

28.An evaluation of the perceived benefits of oppressive rule probably requires more than what is expressed in the claim, 'whatever the costs of Roman conquest and the broader social and political consequences of Roman rule, throughout the empire daily life was certainly safer and more stable' (Hollingshead 1998.5). Alexander (1991:11life was certainly sacer and more stable (Hollingshead 1998.5). Alexander (1991:1112), for instance, quotes a number of sources claiming both the benevolence and the benefits of Empire for its subjects, as well as the protest and denial of advantage brought about by the Roman Empire (including a second-century CE rabbinic dialogue, in which Rabbi Simeon bar Yohai exclaims, 'Everything they [the Romans] have made they have made only for themselves: market-places, for whores; baths, to wallow in; bridges, to levy tolls' (in Šab. 33b).

29. Both in the sense of acknowledging the value of understanding Paul's letters in the light of Empire and its influences, as well as in the sense of accounting for imperial influences in Paul's consciousness (and theology), as reflected in his letters. 
contact with the omnipresent imperial tentacles, since Roman cultural hegemony was particularly strong in the cities and their immediate spheres of influence ${ }^{30}$ (Garnsey \& Saller 1987:203). So more than a socio-historical material reality, the Roman Empire is also a heuristic grid for understanding Paul's vision of the cosmos, life and God, especially in light of his experience of Jesus Christ.

And this is where another approach with different terminology and grammar is needed and which, this article suggests, can be found particularly, but not necessarily exclusively, in postcolonial theory and criticism. ${ }^{31}$ An 'anti-imperialist' reading ${ }^{32}$ cannot simply be equated to a 'postcolonial' reading, since the understanding of what constitutes the postcolonial - and even the imperial - requires consideration. However (and depending on the literary nature of the New Testament documents) a postcolonial approach would want to bear upon the indeterminacy and instability that can be identified in many texts (cf. Burrus 2007:153). The value of postcolonial criticism for studying biblical texts has been established over the last two decades and no longer needs elaborate arguments to justify its use in biblical studies. Postcolonial criticism is not a monolithic enterprise, nor is it beyond criticism (cf. Moore \& Segovia 2005), but its usefulness for the study of the New Testament appears to be settled. And, in focus here, it has the ability to provide a broader interpretative framework, creating the capacity to both frame and analyse imperialism and colonialism ${ }^{33}$ in their hybridity and as contained and reflected in biblical texts. In picking up on surfacelevel and underlying tensions in texts, postcolonial biblical criticism is useful and effective in studying Empire as heuristic grid for biblical interpretation, something that can be illustrated by briefly looking at the concept of mimicry.

\section{Paul and Empire: ideology, ambivalence and mimicry}

In biblical hermeneutics, a postcolonial optic can be framed as an analysis of the texts of early Christianity in and according to a specific context. The broad socio-cultural context of these texts would include the omnipresent, inescapable and overwhelmingly socio-political reality of Empire, imperialism and colonialism around the Mediterranean ${ }^{34}$ as constituted and exercised during the first century CE (cf. Segovia 1998:56). The documentary evidence - sometimes limited to mere hints - about the Empire

30.'The possession of Roman culture was another symbol of the status of a community and its leading members, many of whom continued to use the vernacular as the language of common discourse. Roman rule accentuated rather than broke down the divisions between city and country, rich and poor, local elites and the urban and local masses' (Garnsey \& Saller 1987:203).

31.Postcolonial studies remain, terminologically speaking, a synecdoche (a part which represents the whole; or the whole which represents the part) for imperial and (post) colonial studies. One commentator, in fact, goes further in arguing that it is a 'classic and confusing study of synecdoche', opting rather for the nomenclature 'Imperial/ Colonial Studies' (Segovia 2000b:14 n1).

32. This is partly a problem with terminology: should all forms of political rule and/or government in the Bible simply be portrayed as 'empire', as some scholars appear to do? (cf. Bryan 2005) Greater sensitivity is needed for the most plausible sociohistorical settings, as well as for the intricacies and involved-nature of Empire (as gleaned from social and political sciences): attraction/allure; mimicry; hybridity, etc.

33. Imperialism, as general description of what concerns the centre or metropolis, can be distinguished from colonialism, as that which is related to the margins or periphery (Segovia 2000b:13). In the discussion of Rome and its role and impact the on the commentituted (n) particur easten pats of the ancient world, including subcontinents such as Asia, were among the peipheral aras (Fiesen 2001.17). Imperialism and colonialism each exhibit many faces, register conflicting impacts on human lives and society, and are experienced in a variety of different ways. However, both phenomena are intimately related to structures of political power and ideology, economic structures and practices, and social-cultural configurations and experiences. Used more loosely, colonialism refers to 'any relation of structural domination which relie upon a self-serving suppression of 'the heterogeneity of the subject(s) in question' (Gandhi 1998:85, referring to Talpade Mohanty).

34.Cf. Edward Said's distinction between imperialism and colonialism, as respectively 'the practice, the theory, and the attitudes of a dominating metropolitan city ruling a distant territory' and (as a consequence of imperialism) 'the implanting of settlements on distant territory' (Said 1993:9-10). contained in New Testament texts should not be seen as hidden transcripts (Scott 1990) simply because these texts come from the underside of the Empire. Taking into account that the existence of these documents was largely determined by those who ruled or who had the resources, ability and reason to write, ${ }^{35}$ they were, in another sense, public transcripts of power ${ }^{36}$ within the communities in which they circulated.

An ideologically critical reading of texts therefore has often been an important starting point in New Testament interpretation, also in postcolonial approaches; in fact, ideological criticism has been recognised as one of the most prominent influences and even a kind of centripetal force in postcolonial biblical studies. This is certainly the case as far as the efforts of postcolonial biblical studies are concerned in retrieving the voice of the subjugated and making it audible ${ }^{37}$ (cf. Segovia 2000a:119-132). In as far as ideology is connected to language and meaning, to ideas and systems of thought and belief, in such a way that the interests of the powerful and ruling groups are best served - primarily by presenting their positions and actions as normal and righteous - all texts in their reflection and refraction of reality stand in a relation of some sort to the vested interests of the contexts and people from where they originated ${ }^{38}$ (cf. Rowland 2006:655-671) But when, as in the case of the New Testament, texts serve as both hidden and public transcripts, the value of ideological criticism is curtailed, while other complexities can be addressed, particularly with the use of a postcolonial optic.

As stated at the end of Section 2, the first-century Roman Empire was neither monolithic nor was it imposed in a singular and simplistic fashion on passive and interest-less subjects. The profile of the imperial subject should also not be posited as uncomplicated. Given the interaction between imperial forces and indigenous foreigners, the Empire was in effect the distillation of a sustained interaction between rulers and subjects. ${ }^{39}$ The Roman Empire's overpowering military force cannot be ignored and while words such as oppression and subjection remain fair and accurate descriptions of Empire, at the same time it also bears reminding that Empire is made possible through a series of ongoing choices and negotiations between subjects and rulers. Amid the powerful, political manoeuvres and overtures of powerful imperials, the subalterns were also engaged in negotiating their own positions a new (Price 2004:176). ${ }^{40}$

35.Part of the problem with using postcolonial criticism when discussing biblical and

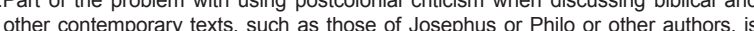
that these texts come from the literate and therefore higher classes, accustomed to that these texts come from the literate and therefore higher classes, accustomed to wealth and influence. In other words, these texts originated with the privileged few of that time, even if privilege in the first-century CE was always a relative concept. The
question, of course, is to what extent and in what way these texts convey something of the life and concerns of people generally (cf. Bryan 2005:25)

36.'A ruling class ideology will offer strategies of legitimation, while an oppositional culture or ideology will often in covert ways seek to contest and to undermine the dominant value system' (Rowland 2006:659).

37. The association of postcolonial biblical criticism with ideology criticism comprises two elements in particular: first, the inevitable link between the ideological nature of texts with vested interests related to social formations and second the impotance texts with vested interests relad to social formations and second, the importance given to socio-political context and the interpreter's stance within it. Ideological is and unconcealed support for certain factions, but also the covert backing and self-justification afforded to the dominant in society. 'It involves laying bare the contradictions in society and the habit which the dominant groups have of neutralizing their potential for resistance and change, for example by co-opting some of the ideas into the dominant ideology (Rowland 2006:657).

38. This does not mean that texts 'have' ideologies (cf. Fowl 1995:15-34), since '[a] text will not usually produce a particular ideology in a 'pure' form' (Rowland 2006:659). However, '[i]t is part of the task of interpretation to lay bare the ambiguities and contradictions that are inherent in all texts' (Rowland 2006:659, 662).

39.'People endure indignities because the coercive power of their rulers gives them no alternative and in some cases because they become habituated to the ideology and rituals that enforce their subordination' (Horsley 2008).

40. Hegemony in postcolonial thought is often posited as domination by consent (Gramsci), 'the active participation of a dominated group in its own subjugation', and regardless of the fact that the subjugated numerically outweigh those exercising power over them the fact that the subjugated numerically outweigh those exercising power over them,
even if the oppressor or army of occupation may have the advantage in terms of even if the oppressor or army of occupation may have the advantage in terms
instruments of subjugation, such as sophisticated weaponry and the like. 'In such 
Postcolonial interpretation wants to acknowledge that imperialism and colonialism are set in such strong ambivalence, particularly where the relationship between the powerful and the powerless is concerned. Here the notion of cultural mimicry is often employed as an analytical tool.

In postcolonial theory, cultural mimicry ${ }^{41}$ - a term coined by Bhabha (1994:85-92) - refers to the imposition of a compelling, cultural framework on the colonised, resulting not only in the coercing of the colonised but also in the internalisation and replication of the coloniser's culture by the colonised - mainly through a process of enticement. The replication is not perfect, however, and neither is it intended as such by the coloniser, since it would erase the all-important boundaries of power between coloniser and colonised. The discourse of mimicry is governed by additional ambivalence: that the colonised may use that very mimicry to mock - and therefore subtly challenge and subvert the control and authority of the coloniser, while simultaneously subverting the coloniser's narcissistic claim to self-identity (Bhabha 1994:85-92). In its submissive subversiveness, mimicry is therefore not only ambivalent through its insistence on and desistence of mimesis; it constitutes the risk for colonisers of having their culture parodied (Moore 2006:110). In fact, mimicry often becomes mockery, exposing the falsity of the claims made, deriding the conventional rhetoric through exaggeration and misapplication, and imitating the claims of Empire and its associates, only to make them appear ridiculous.

Paul's rhetoric to the communities he addressed within the prevailing hegemonic situation ${ }^{42}$ can be understood, for example, along the line of mimicry, which would show that the Roman imperial context is more than an underlying canvas for the firstcentury portrait and indeed also functions as hermeneutic grid. For example, what would the Pauline emphasis on judgement according to works (Rom 2:12-16) have implied in an ideological context in which the superiority of the Roman people was celebrated? On the other hand, how would the Pauline insistence on faithfulness (pistis) 'apart from works (erga)' have resonated when Roman patronage and the 'works' of benefactors determined people's lives and livelihood (as ultimately underwritten by the emperor as benefactor par excellence who readily claimed his 'works' (cf. Augustus and the Res Gestae))? How would Paul's proclamation of one, single ancestor for all people of the whole world, Abraham, as father of faith but also 'impious' (asebēs; Rom 4:5), have been perceived in a world where the imperial ideology focused so strongly on the legacy of piety as exemplified in the portrayal of Aeneas? (cf. Elliott 2007:186)

Criticism of, and opposition to, the practices and claims of the imperial regime that occurred in the 'social space in which offstage dissent to the official transcript of power relations may be voiced' (Scott 1990:xii) were the 'hidden manuscripts' of the oppressed. Criticism and opposition (that no-one dared to express for fear of fatal retribution) form a hidden discourse linked to culture, religion and imperial rule and originate from those who, on the one hand, did not have the resources to record this discourse, or, on the other hand, chose to hide the discourse, not making it public for fear of reprisals. As texts are always imbued with

(Footnote 40 Cont...)

cases . . . the indigene's desire for self-determination will have been replaced by a cases .... the indigene's desire for self-determination will have been replaced by a
discursively inculcated notion of the greater good, couched in such terms as social discursively inculcated notion of the greater good, couched in such terms as

41.Rieger (2007:20 n37) disputes Bhabha's insistence that the ambivalence flowing from mimicry is necessarily a surface effect, arguing that, in addition to surface effect, it can also be symptomatic of repression (in the Freudian sense). Rieger does not see mimicry and repression as mutually exclusive, particularly when the connection (and confusion) between the metaphoric and the metonymic axes are considered.

42. The evidence of uprisings and revolts in the areas where Paul claimed to have been working as apostle is scarce and probably an instance where the exception (insurrection) proves the rule (negotiated domination). ambivalences and ambiguities, ${ }^{43}$ (indicative of the intricaciesof the real-world contexts where they originate) they conceal, ${ }^{44}$ beneath their concern for the dominant or hegemonic, elements more characteristic of the oppositional culture or values (cf. Rowland 2006:655-671). ${ }^{45}$ Through dissenting deference, Paul's mimicry of Empire created the impression that he internalised and replicated imperial culture while he actually used the ambivalence of the hegemonic discourse to his advantage ${ }^{46}$ To some extent, therefore, Paul's public transcripts to communities scattered around the Mediterranean served as hidden transcripts in relation to the Empire.

Postcolonial hermeneutics represents a shift in emphasis, a strategy of reading that attempts to point out what was lacking in previous analyses, as well as to rewrite and correct (Punt 2003:59). Indeed, the postcolonial condition is about more than subscribing to either of the two extremes, of choosing either submission or subversion, but rather comprises unequal measures of aversion and admiration, resentment and desire, rejection and imitation, resistance and cooption, separation and surrender (Moore 2006a:x); therefore, those who found and find themselves engaged by postcoloniality can reflect on such complexities in an appropriately nuanced way. ${ }^{47}$

\section{CONCLUSION}

The analysis of social and political contexts during New Testament times cannot be divorced both from accounting for the history of biblical interpretation ${ }^{48}$ and for the social location and ideological setting of modern scholarship ${ }^{49}$ (cf. Whitelam 1998:45). The realisation that Empire was a pervasive presence in New Testament times and, as a result, finding its traces in these texts, probably does not require postcolonial theory.

43. 'A text will not usually produce a particular ideology in a 'pure' form, whether it be supportive of the status quo or not. Accordingly, however loud the note of protest in a text, it is going to be shot through with the ambiguities of being part and parcel of a world that is itself full of contradiction and pain' (Rowland 2006:659).

44. 'Only with difficulty is it possible to retrieve from the biblical text an alternative perspective to the dominant ideology which has so permeated the text' (Rowland 2006:659).

45.Postcolonial biblical interpretation accepts, with postmodernism, that truth is mapped, constructed and negotiated, and rejects the notion of objective and neutral truth as expressions of political, religious and scholarly power. As far as the Bible is concerned, it is also no longer the meaning of the text that is sought, as a multiplicity of meanings are acknoulged from the outset. This includes the revaluing of the little of meanings are acknowledged from the outset. This includes the revaluing of the little raditions (Meeks), the hidden transcripts (Scott) of the disadvantaged, marginalised and displaced, in other words, the Other embodied in women and minorities. Segovia emphasises that a move beyond an essentialist notion of text vis-à-vis meaning is equired, since it is not texts that contain meaning, waiting to be discovered, but meaning is properly viewed as being constructed in the text-reader interaction.

46.As was shown by Castelli (1991), mimesis is an important mechanism through which Paul stabilised his own discourse of power. Cf. also Punt (2008) for a more sustained discussion on Pauline mimicry in 2 Corinthians 10-13.

47.Cf. Segovia's (1998:57) questions: 'How do the margins look at the 'world' - a world dominated by the reality of empire - and fashion life in such a world? How does the center regard and treat the margins in the light of its own view of the 'world' and life in that world? What images and representations of the other-world arise from either side? How is history conceived and constructed by both sides? How is 'the other' regarded and represented? What conceptions of oppression and justice are to be found?'

48.E.g. the fixation on the notion of progression, or social evolutionism, and in particular also the notion and reality of nation states, have been important factors influencing the interpretative history of biblical text, not only but also in relation to how Empire the interpretative history of biblical text,

49.Intricate hermeneutical mapping exercises characteristic of traditional biblical scholarship, with reference to pre-critical, critical and post-critical approaches, or pre-modern, modern and postmodern eras, or author-centred, text-centred and reader-centred hermeneutics, are subverted by Sugirtharajah's insistence that, from a colonial perspective, only two categories are required and really make sense: colonial and postcolonial (1998:15). This is a distinction that, notwithstanding its apparent simplicity and clarity, hides a vast set of ambiguities. Sugirtharajah's observation is subsumed in Segovia's use and further development of colonialism observation is subsumed in Segovia's use and further development of colonialism/ imperialism to map biblical hermeneutics, when he situates postcolonialism in cultural studies but proceeds to plot biblical criticism, and its major foci, on and according to the postcolonial map, with interesting results (Segovia 1998:56-63) After identing three important foci or dimensions in biblical studies - texts 'texts' or readings of texts, and readers - Segovia aligns them with colonialism/ imperialism and its historical development. 
However, while other critical theories and methodologies ${ }^{50}$ used in the interpretation of the New Testament texts generally either account for the material setting of Empire (through broadranging historical-critical approaches and even socio-scientific methodology), or are engaged in examining the ideological aspects of Empire (with ideological criticism or even feminis criticism), postcolonial theory currently probably offers the best possibility of investigating Empire as both material setting (as cultural production and social matrix) and heuristic grid for New Testament interpretation.

\section{REFERENCES}

Alexander, L., 1991, 'Images of Empire', Journal for the study of the Old Testament, suppl. ser. 112.

Barton, J., 1998, 'Historical-critical approaches', in J. Barton (ed.), The Cambridge companion to biblical interpretation, pp. 9-20, Cambridge, Cambridge University Press.

Bhabha, H.K., 1994, The location of culture, Routledge, London \& New York.

Boron, A.A., 2005, Empire $\mathcal{E}$ imperialism. A critical reading of Michael Hardt and Antonio Negri, Politics, History, International Relations, (KGB 325.32 BOR), transl. J. Casiro, Zed Books, London, New York

Bryan, C., 2005, Render to Caesar: Jesus, the early Church and the Roman superpower, Oxford University Press, Oxford.

Burrus, V., 2007, 'The Gospel of Luke and the Acts of the Apostles', in F.F. Segovia \& R.S. Sugirtharajah (eds.), A Postcolonial Commentary on the New Testament Writings, pp. 133-155, The Bible and Postcolonialism, vol. 13, T \& T Clark, New York.

Carter, W., 2006, The Roman empire and the New Testament: An essential guide. Abingdon, Nashville.

Cassidy, R.J., 2001, Christians and Roman rule in the New Testament, Companions to the New Testament, Crossroad (Herder and Herder Book), New York.

Castelli, E., 1991, Imitating Paul: A discourse of power, Literary Currents in Biblical Interpretation, Louisville, Westminster John Knox.

Chow, J.K., 1997, 'Patronage in Roman Corinth' in R.A. Horsley (ed.), Paul and empire: Religion and power in Roman imperial society, pp. 104-25, Trinity Press International, Harrisville.

Crossan, J.D., \& Reed, J.L., 2004, In search of Paul: How Jesus's apostle opposed Rome's empire with God's kingdom, A new vision of Paul's words and world, Harper San Francisco, New York.

Ehrman, B.D., 2008, The New Testament: A historical introduction to the early Christian writings, 4th edn., Oxford University Press, New York.

Elliott, N., 1994, Liberating Paul. The Justice of God and the Politics of the Apostle, The Bible E Liberation, vol. 6, N.K. Gottwald \& R.A. Horsley (eds.), Orbis, Maryknoll.

Elliott, N., 2007, 'Political formation in the Letter to the Romans', in R.L. Brawley (ed.), Character ethics and the New Testament. Moral dimensions of Scripture, pp. 179-90, WJK, Louisville.

Fowl, SE., 1995, 'Texts don't have ideologies', Biblical Interpretation 3(1), 15-34.

Friesen, S.J., 2001, Imperial cults and the apocalypse of John: Reading Revelation in the ruins, Oxford University Press, Oxford.

Garnsey, P. \& Saller, R., 1987, The Roman Empire: Economy, society and culture, Duckworth, London.

50.Postcolonial theory is, notwithstanding its opposition to modernist approaches to history (linearity, evolutionary progression, etc.), an important asset in making sense of the material setting and related aspects of history, by indeed providing hermeneutical perspective and analytical tools with which to interpret the materialities of the all-encompassing imperial setting. While a historical perspective (and a critical the all that) is important in postcolonial studies, it is doubtful whether the critical (he claim hat 'postcolonalisism' (Kwok ( . On Schüssler Fiorenza (1999.38-39). On the other hand, this is not to deny historica criticism's initial suspicious and against-the-grain readings of ecclesially authorised readings of the Bible (cf. Barton 1998:16-19).
Garnsey, P.D.A. \& Whittaker, C.R. (eds.), 1978, 'Imperialism in the ancient world', Cambridge University research seminar in ancient history, Cambridge University Press, Cambridge.

Gandhi, L., 1998, Postcolonial theory: A critical introduction, Columbia University Press, New York.

Hardt, M. \& Negri, A., 2000, Empire, Harvard University Press, Cambridge.

Hardt, M. \& Negri, A., 2004, Multitude: War and democracy in the age of empire, Penguin Books, New York.

Hengel, M., 1977, Crucifixion in the ancient world and the folly of the message of the cross, SCM, London.

Hollingshead, J.R., 1998, The household of Caesar and the Body of Christ. A political interpretation of the Letters from Paul, University Press of America, Lanham.

Horsley, R.A., 1997, '1 Corinthians: A case study of Paul's assembly as an alternative society', in R.A. Horsley (ed.), Paul and empire: Religion and power in Roman imperial society, pp. 242-252, Trinity Press International, Harrisville.

Horsley, R.A., 2000, 'Rhetoric and empire - and 1 Corinthians', in R.A. Horsley (ed.), Paul and politics, Ekklesia, Israel, imperium, interpretation: Essays in honor of Krister Stendahl, pp. 72-102, Trinity Press International, Harrisville.

Horsley, R.A., 2008, Jesus, the messianic traditions of Israel, and the underground of Galilee, Brazil, n.p.

Kwok, P.L., 2005, Postcolonial imagination and feminist theology, WJK, Louisville.

Lopez, D.C., 2008, Apostle to the Conquered. Reimagining Paul's Mission, Paul in Critical Contexts, Fortress, Minneapolis.

Meeks, WA, 1986, 'A hermeneutic of social embodiment', Harvard Theological Review 79(1-3), 176-186.

Millar, F.,1977, The emperor in the Roman world (31 BC - AD 337) Duckworth, London.

Moore, S.D. \& Segovia, F.F., 2005, 'Postcolonial Biblical Criticism: Beginnings, Trajectories, Intersections, in S.D. Moore \& F.F. Segovia (eds.)', Postcolonial Biblical Criticism. Interdisciplinary Intersections, pp.1-22, The Bible and Postcolonialism, T \& T Clark International, London, New York.

Moore, S.D., 2006b, "Mark and empire: "Zealot" and "postcolonial" readings', in R.S. Sugirtharajah (ed.), The postcolonial biblical reader, pp. 193-205, Blackwell, London.

Moore, S.D. \& Segovia, F.F., 2005, 'Postcolonial Biblical criticism: Beginnings, trajectories, intersections', in S.D. Moore \& F.F. Segovia (eds.), Postcolonial biblical criticism. Interdisciplinary intersections, pp. 1-22, The Bible and Postcolonialism, T \& T Clark International, London.

Price, S.R.F., 1984, Rituals and power: The Roman imperial cult in Asia Minor, Cambridge University Press, Cambridge.

Price, S.R.F., 2004, Response', in R.A. Hosrley (ed.), Paul and the Roman Imperial Order, pp. 175-183, Harrisville, Trinity Press International.

Punt, J., 2008, 'Paul and postcolonial hermeneutics: Marginality and/in early biblical interpretation', in S. Porter \& C.D. Stanley (eds.), As it is written: Studying Paul's use of Scripture, Symposium Series, vol. 50, pp. 261-290, SBL Publications, Atlanta.

Punt, J., 2003, 'Postcolonial biblical criticism in South Africa: Some mind and road mapping', Neotestamentica 37(1), 59-85.

Rieger, J, 2007, Christ and Empire. From Paul to postcolonial times, Fortress, Minneapolis.

Richey, L.B., 2007, Roman Imperial Ideology and the Gospel of John. Catholic Biblical Quarterly Monograph Series, vol. 43, Catholic Biblical Association of America, Washington.

Rowland, C., 2006, 'Social, political, and ideological criticism', in J.W. Rogerson \& J.M. Lieu (eds.), The Oxford handbook of biblical studies, pp. 655-671, Oxford University Press, Oxford.

Said, E., 1993, Culture and imperialism, Knopf, New York.

Scarre, C., 1995, Chronicle of the Roman emperors: The reignby-reign record of the rulers of imperial Rome, Thames and Hudson, London.

Schüssler Fiorenza, E., 1999, Rhetoric and ethic: The politics of biblical studies, Fortress, Minneapolis. 
Schüssler Fiorenza, E., 2007, The power of the word: Scripture and the rhetoric of empire, Fortress, Minneapolis.

Scott, J.C., 1990, Domination and the art of resistance: Hidden transcripts, Yale University Press, New Haven and London.

Segovia, F.F., 1995, 'The text as Other: Towards a Hispanic American hermeneutic', in D. Smith-Christopher (ed.), Text $\mathcal{E}$ experience: Towards a cultural exegesis of the Bible, 'Biblical Seminar', vol. 35, pp. 276-298, Sheffield Academic Press, Sheffield.

Segovia, F.F., 1998, 'Biblical criticism and postcolonial studies: Towards a postcolonial optic', in R.S. Sugirtharajah (ed.), The postcolonial Bible, the Bible and postcolonialism, vol. 1, pp. 49-65, Sheffield Academic Press, Sheffield.

Segovia, F.F., 2000a, 'Interpreting beyond borders: Postcolonial studies and diasporic studies in biblical criticism', in F.F. Segovia (ed.), Interpreting beyond borders, pp. 11-34, The Bible and Postcolonialism, vol. 3, Sheffield Academic Press, Sheffield.
Segovia, F.F., 2000b, 'Reading-across: Intercultural criticism and textual posture' in F.F. Segovia (eds.), The Bible and postcolonialism, pp. 59-83, The Bible and Postcolonialism, vol. 3, Sheffield Academic Press, Sheffield.

Segovia, F.F. \& Sugirtharajah, R.S., 2007, A postcolonial commentary on the New Testament writings, The Bible and postcolonialism, vol. 13, T \& T Clark, New York.

Sugirtharajah, R.S., 1998, Asian Biblical Hermeneutics and Postcolonialism: Contesting the Interpretations, The Bible and Liberations, Orbis, Maryknoll.

Swartley, W.M., 2006, Covenant of peace: The missing peace in New Testament theology and ethics, Eerdmans, Grans Rapids.

White, J.L., 1999, The apostle of God: Paul and the promise of Abraham, Hendrickson, Peabody.

Whitelam, K.W., 1998, 'The social world of the Bible', in J. Barton (ed.), The Cambridge companion to biblical interpretation, pp. 35-49, Cambridge Companions to Religion, Cambridge University Press, Cambridge.

Wright, N.T., 2005, Paul: In fresh perspective, Fortress, Minneapolis. 